\title{
Japan-Supported Biomass Energy Projects Technology Readiness and Distribution in the Emerging Southeast Asian Countries: Exercising the J-TRA Methodology and GIS
}

\author{
Andante Hadi Pandyaswargo, Da Pang, Issui Ihara, and Hiroshi Onoda
}

\begin{abstract}
Biomass is a promising energy resource for the Southeast Asian countries. There are currently many biomass related technology development projects taking place in the emerging countries of the region (Thailand, Indonesia, Viet Nam, Myanmar, Philippines, Malaysia, Cambodia, Laos). In this paper, we investigate the critical characteristics of Japan-supported biomass energy technology development projects in those countries, specifically on; technology type, biomass feedstock type, the technology's readiness, and the geographical location. Information about the projects was collected from major Japanese organizations and Japanese private companies' websites. The results highlight the trends and direction of biomass energy conversion technology development in the region. Among them are the following: 1) Biorefinery is the most popular technology used in the development projects mainly in Thailand, 2) Boiler, Turbine, Generator (BTG) projects exist in all countries discussed in this study, 3) Agricultural residue from rice plantation and Oil Palm are the two most popular type of feedstocks used in the projects, 4) Most of the projects' are still in "feasibility study" and "pilot demonstration" readiness levels.
\end{abstract}

Index Terms-Biomass projects, Japan, Southeast Asia, technology readiness.

\section{INTRODUCTION}

Emerging countries in the Southeast Asia region produce a significant amount of various types of agricultural biomass, such as sugarcane, cassava, and rice [1] that are significant as the staple food supply for the local people. At the same time, the traditional use of its residues (such as rice husks and straw) and locally grown biomass for heating and cooking (such as fuelwood) has been practiced region-wide for centuries and remains the primary use of biomass for energy in the region. Solid biomass accounts for $20 \%$ of the Southeast Asian energy mix for the total demand in 2016 [2] and traditional uses of bioenergy occupy $69 \%$ of the Association of Southeast Asian Nation (ASEAN) total final energy

Manuscript received July 25, 2019; revised November 1, 2019. This work was supported in part by the Japan Science and Technology Agency, Strategic International Collaborative Research Program (JST SICORP), under the e-Asia Feasibility Study on Social Implementation of Bioenergy in East Asia.

A. H. Pandyaswargo, D. Pang, and H. Onoda are with the Waseda University, Graduate School of Environment and Energy Engineering, 3-4-1 Okubo, Shinjuku-ku, Tokyo, 169-8555, Japan (e-mail: andante.hadi@aoni.waseda.jp, pangda0708@akane.waseda.jp, onoda@waseda.jp).

I. Ihara is with the Deloitte Tohmatsu Consulting LLC., Marunouchi Nijubashi Building, 3-2-3 Marunouchi, Chiyoda-ku, Tokyo, 100-8361, Japan (e-mail: iihara@tohmatsu.co.jp). consumption of renewable energy in 2014 [3]. The practice of using biomass energy in traditional ways (mainly direct combustion for cooking and heating) is inefficient and emits air pollution that is harmful to human health [4]. Both the use and planting of biomass should be done sustainably [5]. A proper storage and transport system for solid biomass to power local electrification could allow expanded options for where and when the energy is used. Electrification in the rural area can indirectly support opportunities for social and economic development [6] by influencing critical components of poverty, namely; health, education, income, and environment [7]. In 2016, 65 million people in Southeast Asia still lived without access to electricity [2]. Most of them live in Myanmar (22 million or $41 \%$ of the national population), Indonesia (23 million or $9 \%$ of the national population), the Philippines (11 million or $10 \%$ of the national population), and Cambodia (6 million or $40 \%$ of the national population) [2]. Many of the emerging Southeast Asian countries are aiming for universal electrification. For example, Myanmar is aiming for universal electrification by 2030 [8], Indonesia targeted a 99.9\% electrification rate by 2019 [9], Cambodia aims to have all villages electrified by 2020 [10], the Philippines aims to meet all electricity demand by 2040 [11], and Laos aims to provide electricity to $94 \%$ of households in the country by 2020 [12]. While more research is needed to understand the sustainability of the use biomass to support the achievement of electrification targets (a Life Cycle $\mathrm{CO} 2$ study was conducted to measure the $\mathrm{CO} 2$ emission of using imported woody biomass for co-firing in coal plant to generate electricity [13]), it has allowed the replacement of fossil-fuel-based energy in various sectors. Especially for the transport, building, and industrial sectors, the use of biomass could provide a little under two-thirds of renewable energy used for heat and fuel [14]. Presently, approximately $20 \%$ of the energy mix in the Southeast Asian region is from a renewable resource, and the goal is to achieve a 35\% share by 2023 [3]. Worldwide, both the public and private sectors have invested in the development of technology to improve the effectiveness and efficiency of biomass energy conversion technology [15]. Indicators of readiness of technologies may include reducing costs, expanding markets, improved integration with the existing infrastructure, the improvement of safety, and risk reduction [16]. In Southeast Asian countries, Japan has been active in the promotion of biomass energy projects [17], the development of biomass energy sustainability standards [18], [19], research collaborations [20], and the establishment of demonstration projects [21]-[23]. This study analyzed 86 
projects supported by the Japanese government and Japanese organizations and companies in 8 emerging Southeast Asian countries (Indonesia, Thailand, Myanmar, Viet Nam, Laos, Philippines, Cambodia, and Malaysia) at various stages of implementation. Information about these projects was collected from the Japanese organizations' open and semi-open (accessible by registration) databases available on the websites of Japan International Cooperation Agency (JICA), New Energy and Industrial Technology Development Organization (NEDO), and Global Environment Centre Foundation (GEC) and on websites of Japanese companies that run biomass energy projects in the region.

The present paper presents the characteristics of the existing Japan-supported biomass energy conversion technology development projects in the Southeast Asian region, in particular, providing the following information: technology types, biomass feedstock type, the technology's readiness, and the geographical location of the projects. This paper is also an update to a previous Southeast Asia biomass projects analysis that was published more than a decade ago [24]. Last, by identifying the bottleneck of technology development readiness assessment in this study, decision-makers could accelerate their technology development progress through troubleshooting the correct problematic area.

\section{Methodologies}

\section{A. Literature Review and Database Construction}

To provide a background information on the existing biomass resources, power generation potential, and the related national policies and regulatory environment in Southeast Asia, a literature review of previously published journal articles and news was conducted. For analysis on the technology readiness, biomass feedstock type, technology type, and geographic location of Japan-supported biomass projects in emerging ASEAN, a biomass project database were constructed utilizing the open-source database from JICA, NEDO, GEC, and Japanese companies' websites. The database consists of the biomass project detailed information such as the organization and companies involved in the projects, the location of the project (country and province/town), the feedstock type, the technology used, the output/product, the capacity, the year of the project, the name of the project, the readiness level, the website Uniform Resource Locator (URL), and other relevant information entered in the note section. In this study, only projects taking place in the emerging countries in ASEAN region (Thailand, Indonesia, Viet Nam, Myanmar, Philippines, Malaysia, Cambodia, Laos) between 2010 and 2018 were included in the database.

\section{B. Japanese Technology Readiness (J-TRA) Method}

The Japanese Technology Readiness (J-TRA) method is an adaptation from the United States' Technology Readiness Assessment (TRA). The development process and the complete application procedure of J-TRA Methodology have been explained in our previous publication [16], [25], [26].
The J-TRA has seven parameters to determine the readiness level of a project. These parameters are the following; A) Market, B) (Technology) Development, C) (Technology) Integration, D) Verification, E) Safety, F) Commercialization, and G) Cost and risk. In each parameter, there is a compliance checklist. The full description of the compliance checklist for all of the parameters could be found in the manual published by the Japanese Ministry of Environment [27]. The result of J-TRA is presented by the Technology Readiness Level (TRL). There are eight levels of TRL, with level 1 as the lowest level (usually at a research experiment level, identified by the existence of research paper as evidence) and level 8 as the highest level (usually projects that have been fully commercialized in the intended environment). To determine the TRL of a project, the scoring matrix shown by Table I is referred. There are 6 categories in the scoring matrix; A (Market), B (Development), C (Integration), D (Verification), E (Safety), F (Commercialization), and G (Cost and Risk). Only when all the items in each TRL is satisfied, a project can be scored as the corresponding TRL.

TABLE I: TRL SCORING MATRIX

\begin{tabular}{|c|c|c|c|c|c|c|c|}
\hline TRL & $\mathbf{A}$ & B & $\mathbf{C}$ & D & $\mathbf{E}$ & $\mathbf{F}$ & $\mathbf{G}$ \\
\hline 1 & A-1 & B-1 & & D-1 & & & \\
\hline 2 & A-2 & B-2 & & D-2 & & & \\
\hline 3 & A-3 & B-3 & C-1 & D-3 & E-1 & F-1 & G-1 \\
\hline 4 & $\begin{array}{l}\text { A-4 } \\
\text { A-5 }\end{array}$ & B-4 & C-2 & D-4 & E-2 & F-2 & G-2 \\
\hline 5 & A- 6 & B-5 & C-3 & D-5 & E-3 & F-3 & G-3 \\
\hline 6 & A-7 & B-6 & C-4 & D-6 & E-4 & F-4 & G-4 \\
\hline 7 & \multicolumn{7}{|c|}{$\begin{array}{l}\text { The equipment and systems have been finalized. Manufacturing } \\
\text { and introduction processes has been completed. }\end{array}$} \\
\hline 8 & \multicolumn{7}{|c|}{$\begin{array}{l}\text { Manufacturing and introduction processes has been completed } \\
\text { and is in the stage of mass production of products. }\end{array}$} \\
\hline
\end{tabular}

Source: [17]

\section{Geographic Information System (GIS)}

To show the geographical location of the collected biomass projects in the database, the QGIS software was used to plot the project locations (town/province) in the map of each country.

\section{LITERATURE REVIEW AND DATABASE ANALYSIS}

\section{A. Biomass Resources and Power Generation Potential in Emerging Southeast Asia}

Biomass is among the most untapped renewable energy resources in the Southeast Asian region. The region has an annual biomass potential of $42 \mathrm{M}$ ton [28]. Most biomass is generated in Indonesia (32.6 M ton/year), and a significant amount is located in Myanmar (4.2 M ton/year) and Thailand (2.5 M ton/year) [29]. Based on [1], the main types of agricultural biomass produced in most countries in the region are cassava, coconuts, bananas, sugarcane, rice paddy, and oil palm. The primary types of woody biomass produced in the region are rubber, bamboo, teak, and acacia. Among them, acacia, bamboo, coconut palm, eucalyptus, rubber, pine, and teak have significant energy generation potential. Bamboo, in particular, is categorized as a low-maintenance energy crop, as it grows quite quickly without much effort required for 
maintenance and intervention. Oil palm is known to be among the highest yielding crops compared to other oil-producing crops [28].

It has been estimated that the advanced biofuel potential from residues, land freed by closing the yield gap, land freed by eliminating waste and losses in the food chain, and trees in forest land in the region would sum to approximately 14,644 PJ of total primary energy potential annually [1]. The development of the use of biomass energy for both buildings/electrification and transport fuel plays a significant role in increasing the share of biomass energy use.

\section{B. Policy and Regulatory Environment}

The countries in Southeast Asia generally have considerably supportive policies that create a conducive environment for advancing biomass energy generation. The most tangible governmental support is perhaps the feed-in-tariff (FIT) mechanisms introduced in the majority of the countries in the region (Table II). Thailand was the first among those countries in the region that introduced FIT for renewable energy in 2007 [30]. The tariff for biomass-based electricity in Thailand had been revised twice thus far, in 2009 and 2014. Thailand also currently offers a relatively higher tariff for biomass (16.97 JPY/kWh for $1 \mathrm{MW}$ to $3 \mathrm{MW}$ capacity) [31] compared to other countries in the region (Table I). However, the highest offered tariff is in Indonesia, at 18.80 JPY/kWh for biogas plants lower than $1 \mathrm{MW}$ [32]. This policy has motivated household-scale biogas plants using animal slurry and small food industries in the country, resulting in the establishment of 14,173 anaerobic digestion (AD) plants in 9 provinces by 2018 [33]. Malaysia has the most complex pricing categories, which are based on the capacity of the biomass-based power plant; for up to $10 \mathrm{MW}$ capacity, the price is $8.44 \mathrm{JPY} / \mathrm{kWh}$, for $10 \mathrm{MW}$ to $20 \mathrm{MW}$ capacity, the price is 7.90 , and for $20 \mathrm{MW}$ to $30 \mathrm{MW}$ capacity, the price is $7.35 \mathrm{JPY} / \mathrm{kWh}$ [34]. With similar detailed pricing ranges, there is also a list of tariffs for biogas plants that reduces with an increase in plant capacity. Malaysia only offers 16 years of payment, shorter than the other countries in the region, which commonly offer 20 years of payment for all biomass/biogas-based energy. The Malaysian government argues that biomass plants often have a quicker payback time period compared to other types of renewable energy investment. The grid electricity (mainly from fossil fuel) prices in the Philippines are among the highest in the region, at 19.21 JPY/kWh [35], at nearly the price of electricity in Japan (19.52 JPY/kWh) and only second to Singapore among the Association of Southeast Asian Nation (ASEAN) countries, making FIT rather attractive in the Philippines [36]. While Viet Nam offers FIT mechanism [37], the neighboring countries Laos, Myanmar, and Cambodia currently do not [30].

TABLE II: FEED-IN-TARIFFS IN EMERGING SOUTHEAST ASIAN COUNTRIES

\begin{tabular}{lllll}
\hline \hline Country & $\begin{array}{l}\text { Year of } \\
\text { Implementation }\end{array}$ & $\begin{array}{l}\text { Contract } \\
\text { duration } \\
\text { (year) }\end{array}$ & Conditions & $\begin{array}{l}\text { FIT rate } \\
(\mathrm{JPY} / \mathrm{kWh}) * *\end{array}$ \\
\hline Indonesia & 2012 & 20 & $\begin{array}{l}\text { Biomass } \\
\text { (medium } \\
\text { voltage) } \\
\text { Biomass (low } \\
\text { voltage) }\end{array}$ & $9.10 \times \mathrm{F}^{*}$ \\
& & & $11.87 \times \mathrm{F}$
\end{tabular}

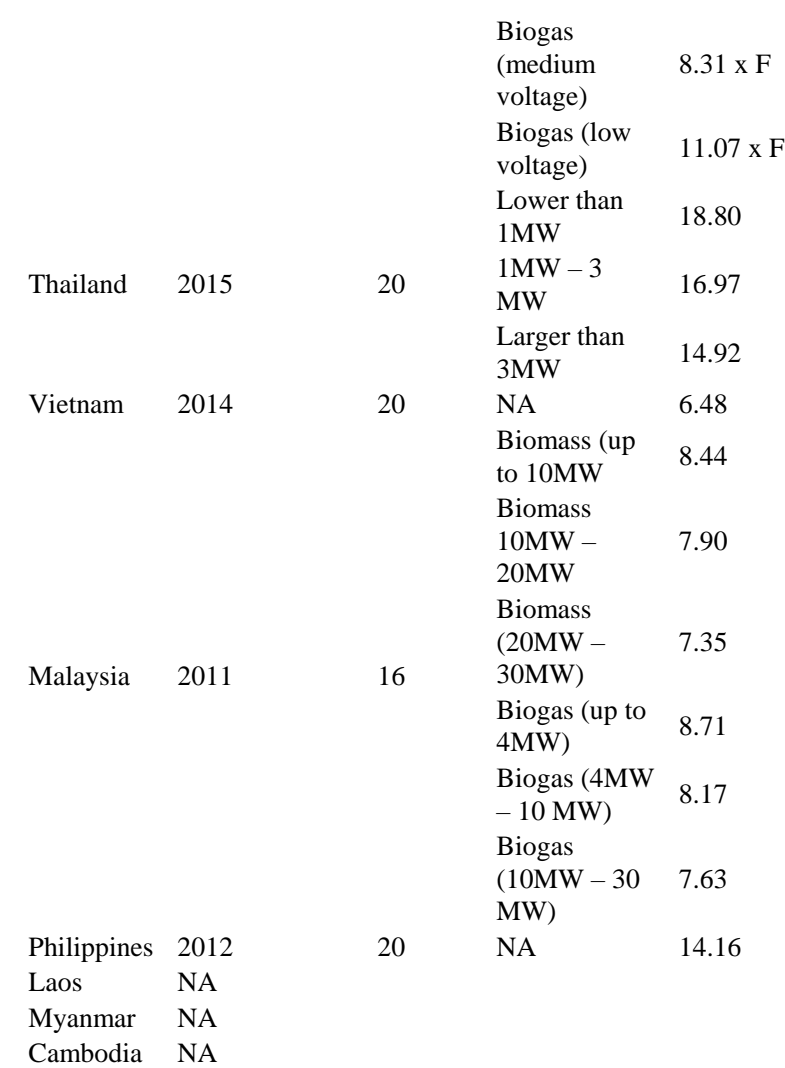

* Factor / Territorial bonus based on the location (province) of the project ** Conversion rate June 2019

Source: Compiled by author from [30]-[35]

In addition to electrification, biomass energy is also used as biofuel for vehicles. The most popular fuel is B20, a blend of $20 \%$ biodiesel and $80 \%$ regular diesel, which is rapidly commercializing in the region. Indonesia introduced the mandatory use of B20 for all diesel engines operating in the country starting from September 2018 [38]. In Thailand, B20 is recommended for the heavy commercial vehicle and public transportation sectors starting from July 2018, but the regulation is not mandatory at the moment [39]. In Malaysia, the mandate requires the selling of B10 (a blend of $10 \%$ biodiesel and $90 \%$ regular diesel) in all fuel stations starting from February 2019 [40].

\section{Japan-Supported Biomass Energy Technology Development Projects in Southeast Asia}

Japanese technologies related to biomass energy have been used in projects in a number of Asian countries, especially in the ASEAN region [17]. To better understand the characteristics of these biomass projects, we collected information on biomass energy technology development projects using the online search engine and created a database of those projects in an excel workbook. Initially, we found over 150 projects, but we found that many of them were the same project in different development stages. We merged such projects to avoid overlapping. Furthermore, because technology develops rapidly, we limited the database to only consist of those taken place after the year 2010. As a result, there are 86 eligible projects for analysis in this study. Most of the project information was found in the database of Japanese organizations such as JICA, NEDO, and GEC. While the JICA and GEC (the foundation that manages the Joint Crediting Mechanism (JCM) databases were open to the 
public, the NEDO database containing the full report of the project was password-protected, and access was granted through registration. Other project information was found on the websites of Japanese private companies. Most of the information was only available in the Japanese language, although in some cases, summaries were provided in the English language. We have translated the critical information from those available only in Japanese. Since the mentioned organizations are the most prominent development funding organizations in Japan, together with the projects collected from the Japanese private companies' websites, the 86 projects represent a comprehensive representation of the most significant biomass energy technology development projects in the region at various development phases.

\section{Types of Technology}

Among the 86 biomass energy technology development projects collected in our database (Fig. 1), the highest number of projects are located in Thailand, with a total of 17 projects. Indonesia is in the second position, with 16 projects, followed by Vietnam (14), the Philippines (11), and Myanmar (11). Among the types of technologies in our database, biorefining is among the most practiced. These biorefinery projects used different types of feedstock such as cassava, Palm Oil Mill Effluent (POME), waste food oil, and bagasse. The number of biorefinery projects is highest in Thailand, with nine projects, followed by the Philippines (5), Myanmar (4), and Indonesia (4). Boiler, turbine, generator (BTG) technology (including direct combustion, co-firing, and incineration-based projects) were in all countries in the region, with the highest number being in Myanmar (4), Viet Nam (4), and Malaysia (3). Anaerobic digestion is also among the most practiced technologies, with Indonesia (5) and Viet Nam (4) leading. Pelletizing (together with chipping and compression to briquets) technology development projects were found in a small number in Thailand (1), Vietnam (1) and Myanmar (2), despite its considerable attractiveness for Japan due to its high transportability. Carbonization (including pyrolysis and torrefaction) is also a potentially attractive technology for Japan because it is commonly used to improve the transportability, quality, and storage ability of biomass fuel to improve resistance to moisture and heating value [33], but only a few such projects were found in Indonesia (3), Myanmar (1), and Cambodia (2).

\section{E. Primary Feedstock}

As shown in Fig. 2, the most common feedstock used in the projects is rice husks, with the highest number being in Myanmar (6), followed by Cambodia (5), Vietnam (2), the Philippines (1), and Laos (1). While rice is a staple food that is quite common in the region, the plantation residue is commonly utilized for farm animal feedstock. The technologies used in technology development projects using rice husks vary from gasification to BTG or carbonization. Another common feedstock is municipal waste, with the highest number of projects being in Vietnam (4), Indonesia (2), Myanmar (2), Philippines (2), and Malaysia (1). There are also several projects using oil palm, but they are localized in Indonesia (9) and Malaysia (6). There is also a small number of projects using oil palm found in Myanmar (2). The part of oil palm used as feedstock in technology development projects includes empty fruit bunch (EFB), palm kernel shells (PKS), and other residues using pelletizing, gasification, and biorefinery technologies.

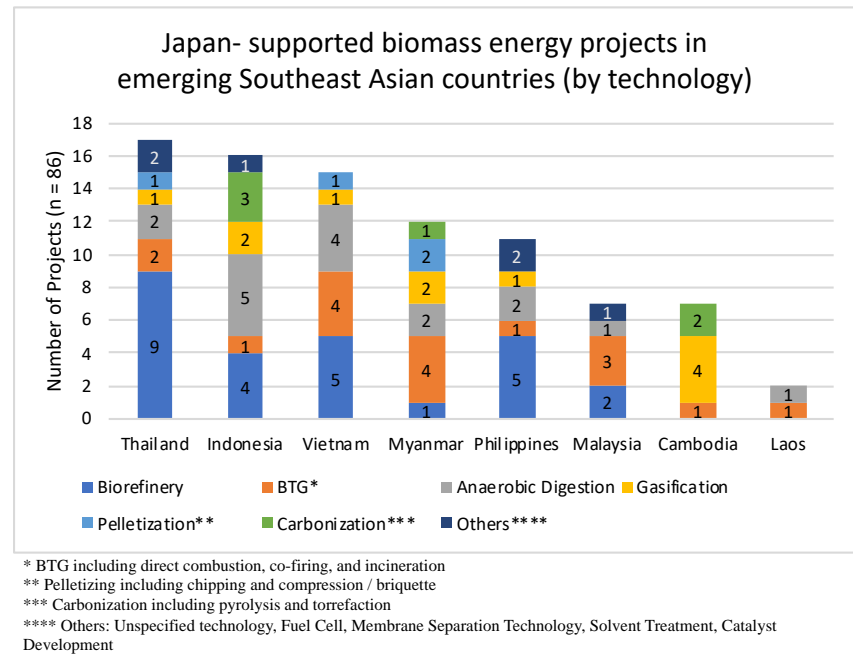

Fig. 1. Biomass energy technology development projects (by technology).

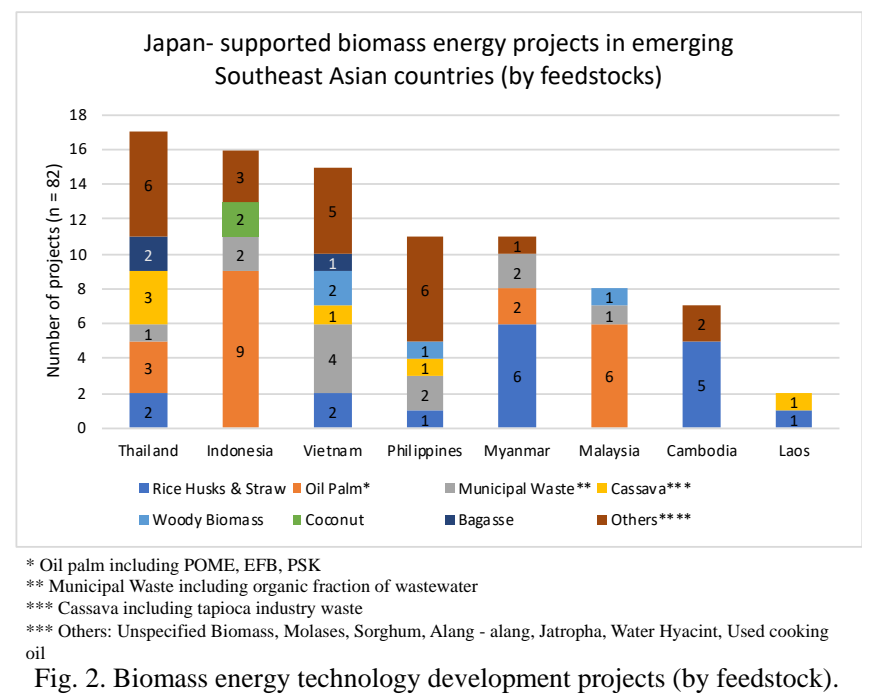

Fig. 2. Biomass energy technology development projects (by feedstock).

\section{Technology Readiness LeVels And the Projects' BOTTLENECKS}

Based on the information provided at the original resources, most of the technology development projects listed in our database are at the feasibility study and pilot demonstration stage (Figs. 3 and 4). Among the feasibility study projects, biorefining, BTG, and AD are the most practiced technologies. Among the pilot demonstration projects, biorefining stands out with 11 projects, followed by BTG, AD, and gasification technologies. Most pelletizing technology-based projects are still in the experimental research stage. Moreover, while almost all major types of technology are available in small numbers in the full operation stage, they have not necessarily reached full commercialization capacity. Looking at the feedstocks used at different levels of project technology readiness, the majority of the projects with high readiness levels use oil palm, rice husks, straw, and municipal waste.

To understand in detail about the readiness level and the 
bottlenecks of the project developments, the J-TRA was applied to all of the projects in the constructed database. Fig. 3 shows an example result of J-TRA application on project No. 16 (from the database) that is located in North Kalimantan, Indonesia. This project used coconut shell and Oil Palm Empty Fruit Bunch (EFB) as feedstock to make biochar intended for rural electrification. It can be observed that the lowest TRL are on the market, commercialization, and cost/risk area. These are the areas that potentially require more attention to improve the readiness level of the project. To present the general performance of the 86 analyzed projects, the TRL results from the highest readiness level of each technology category in the 8 ASEAN countries is presented in Fig. 6.

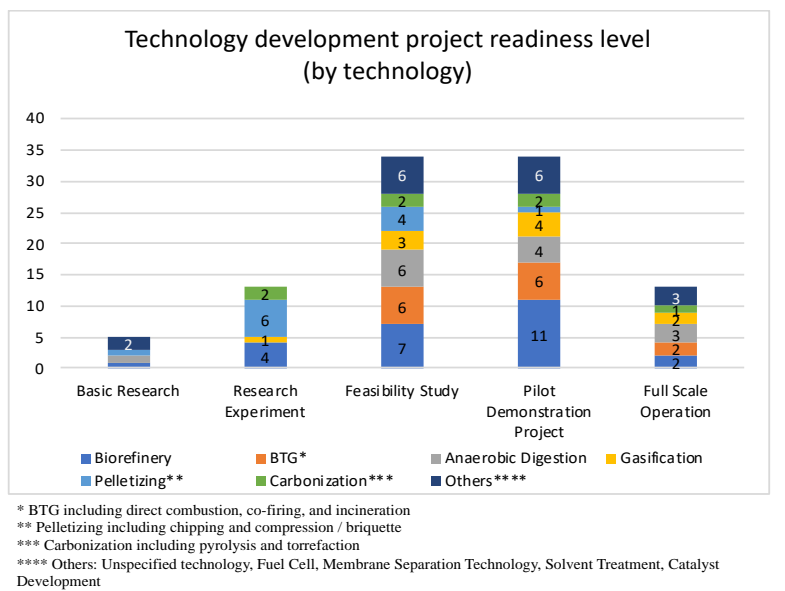

Fig. 3. Technology development project readiness levels (by technology).

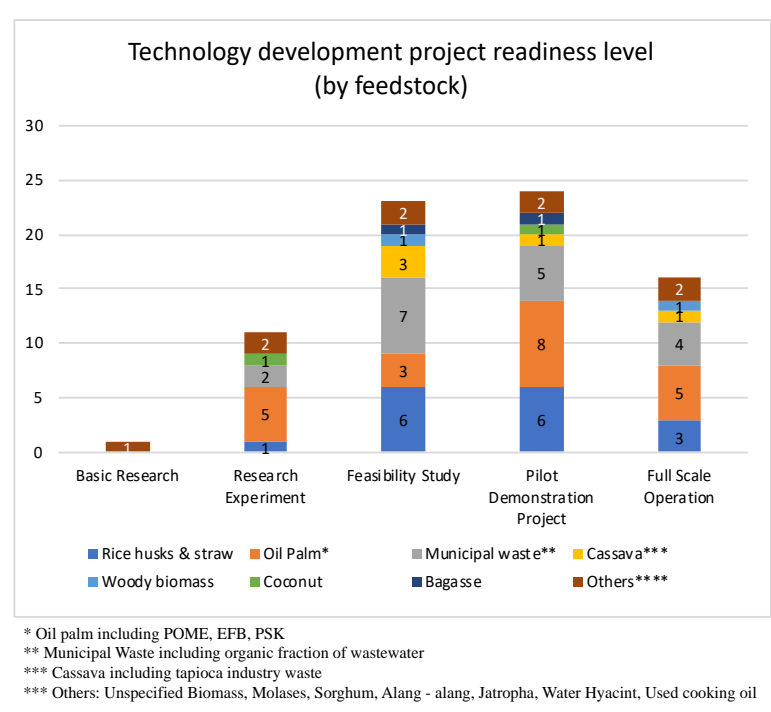

Fig. 4. Technology development project readiness levels (by feedstock).

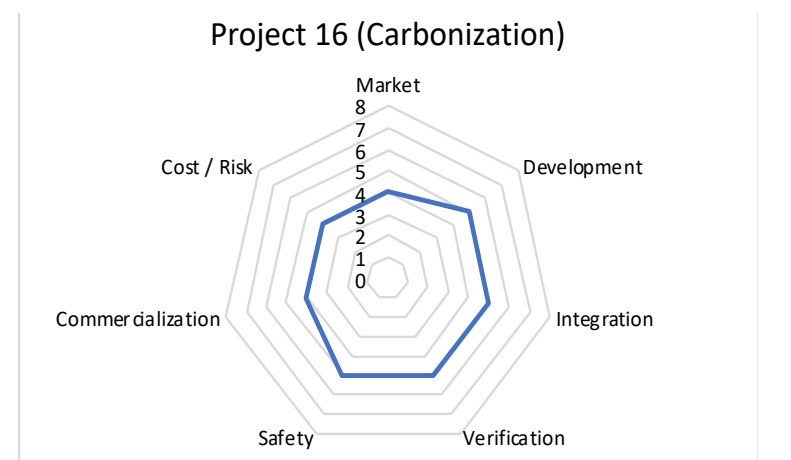

Fig. 5. An example of J-TRA application result in a biomass project in Indonesia.

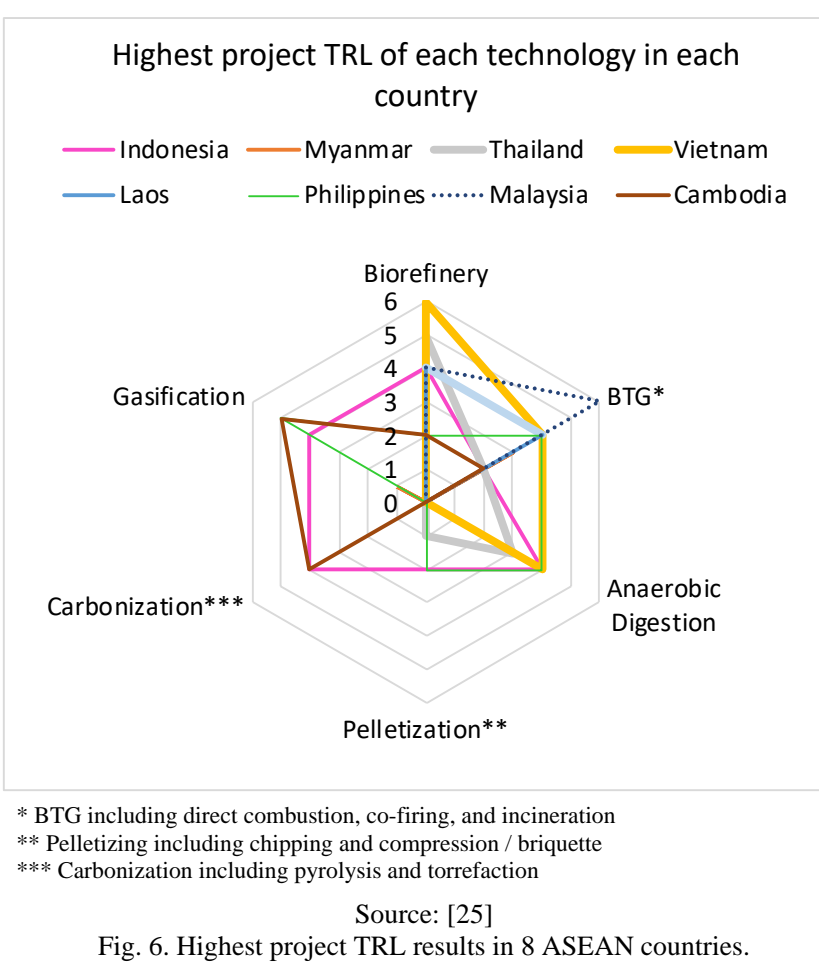

\section{GIS MAP RESULTS}

The geographical location of Japan-supported biomass energy technology development projects is plotted in the corresponding countries based on their feedstock using QGIS software, as shown in Figs. 7-14. In Thailand, most of the projects are concentrated in the central and north-eastern area, with oil palm dominating the central area and cassava dominating the north and north-east. In Indonesia, projects are concentrated in Java and Sumatera, with primary feedstocks being different types of oil palm residues. In Viet Nam, projects are concentrated at both ends of the main island - the south and the north. Agricultural residue-based projects such as rice plantations exist at both ends. In the Philippines, projects are quite evenly distributed throughout the country. More projects are using industrial and residential residue (waste from animal husbandry, municipal waste, and cooking oil) than are using agricultural residue-based projects. In Malaysia, the projects are concentrated in the peninsula, with oil palm as the dominant feedstock. In Cambodia, projects are mainly located near the capital, Pnom Penh, and the biggest lake, Tonle Sap, with most projects using rice husks as the primary feedstock. One rice husk-based project is also found in the neighboring country, Laos. In general, projects are concentrated near the capital cities instead of near where the biomass resources are located. Taking Indonesia as an example, there are a significantly higher number of projects on Java island than on Kalimantan island because many of the projects are still at the demonstration project level, where accessibility plays a more critical role than proximity to resources. Another possible factor is political stability; there is no project located in the conflict-prone southern area of Myanmar. While these factors are understandable considering the readiness level of the projects, the actual implementation of full-scale projects must consider locations that are closer to the source of feedstock and the end-users, such as unelectrified areas, to 
minimize the environmental burden of transportation as well as loss in transmission and distribution.

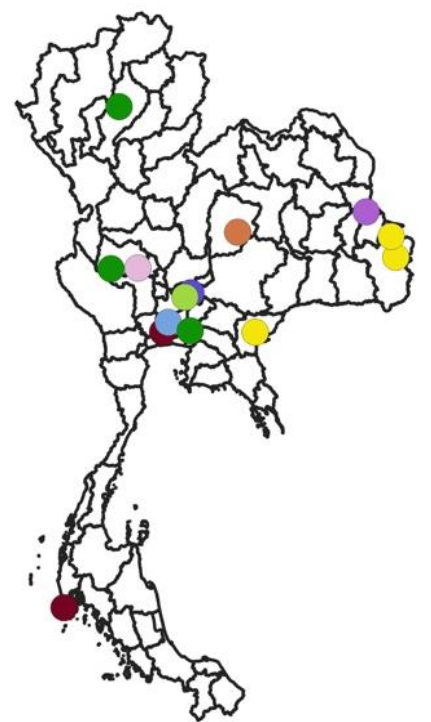

Bagasse

- Biomass Residues

Cassava

Lignite + Biomass

Municipal Waste

Non-food Biomass

Palm Oil

POME

Rice Husks

Sugarcane Bagasse

Fig. 7. The geographical location of the Japan-supported biomass projects in Thailand (by feedstock).

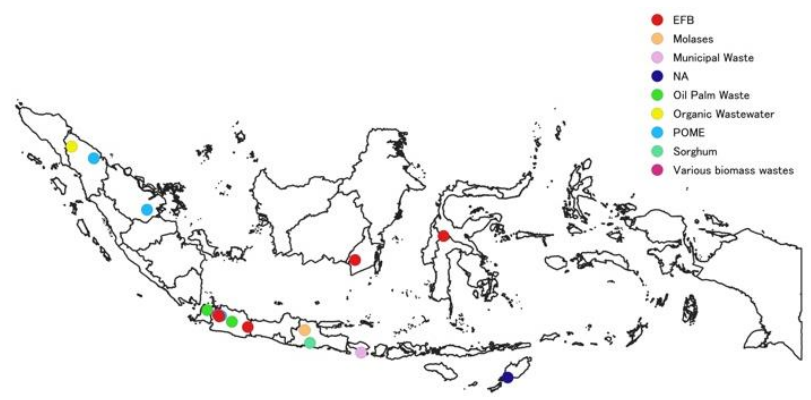

Fig. 8. The geographical location of the Japan-supported biomass projects in Indonesia (by feedstock).

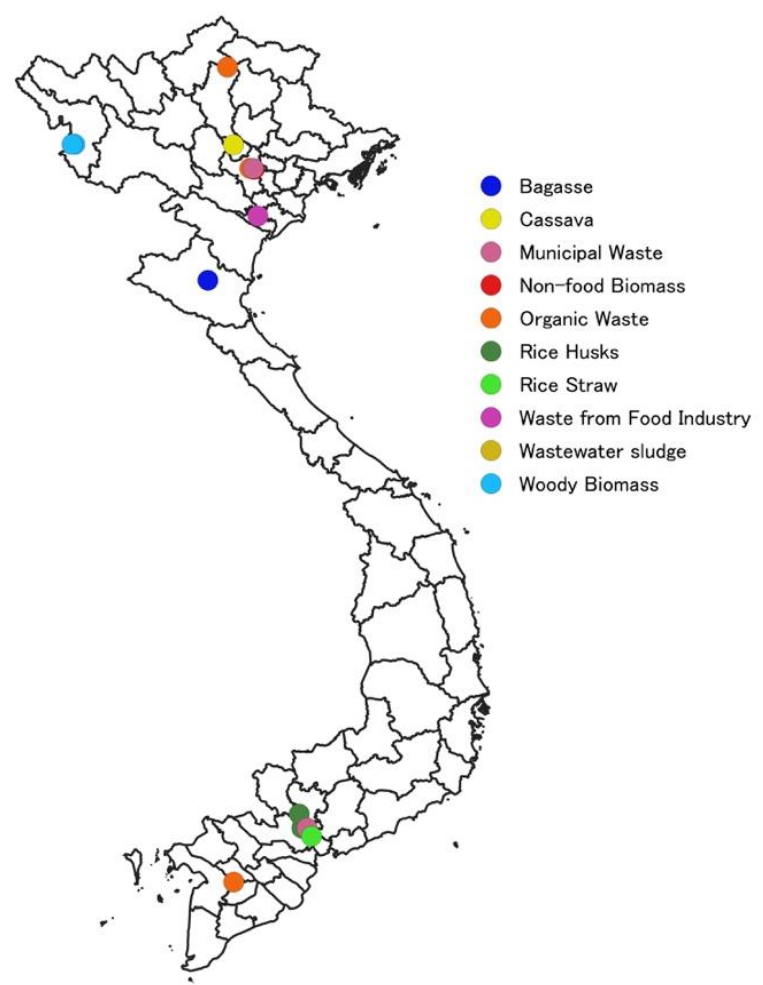

Fig. 9. The geographical location of the Japan-supported biomass projects in Vietnam (by feedstock).

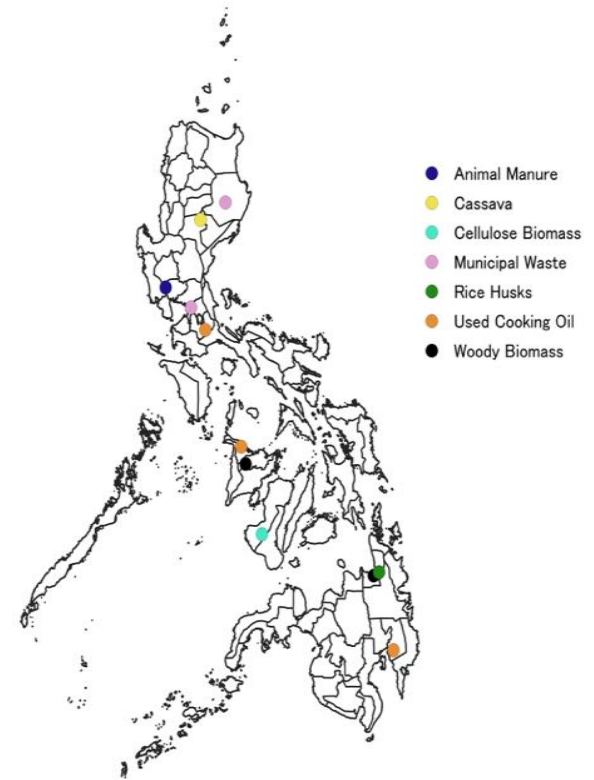

Fig. 10. The geographical location of the Japan-supported biomass projects in the Philippines (by feedstock).

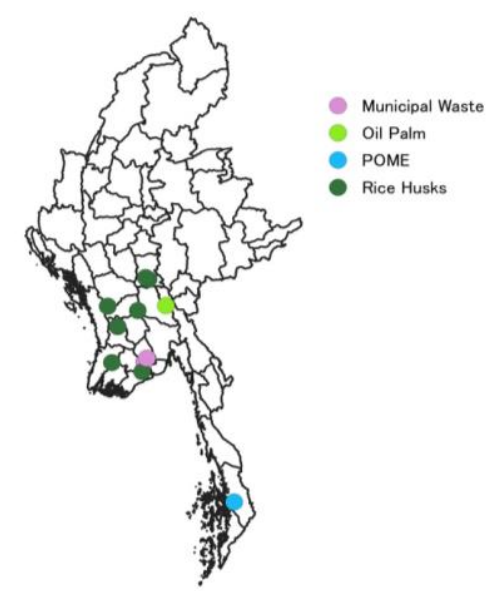

Fig. 11. The geographical location of the Japan-supported biomass projects in Myanmar (by feedstock).

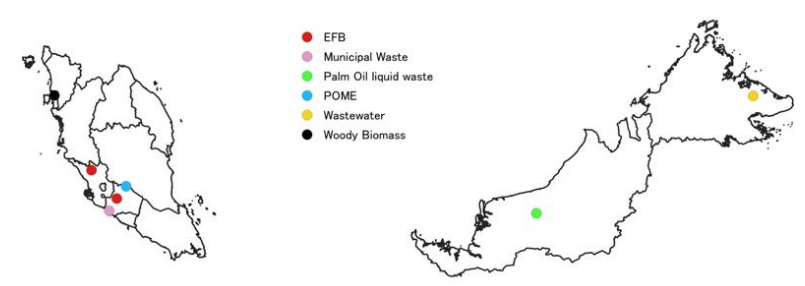

Fig. 12. The geographical location of the Japan-supported biomass projects in Malaysia (by feedstock).

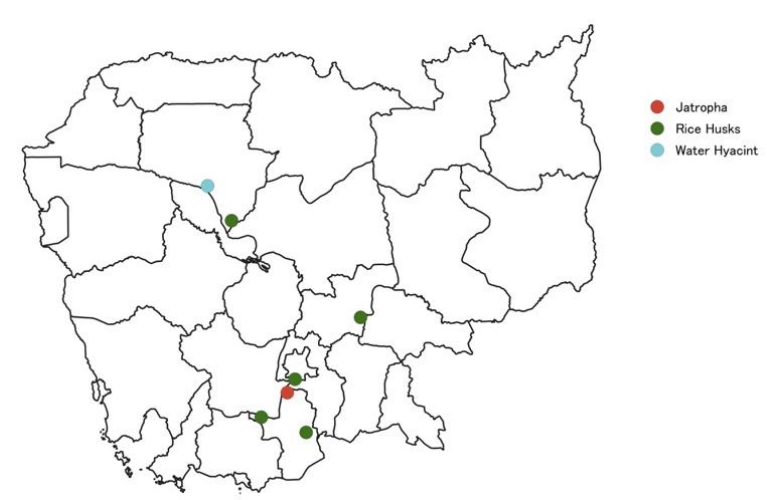

Fig. 13. The geographical location of the Japan-supported biomass projects in Cambodia (by feedstock). 


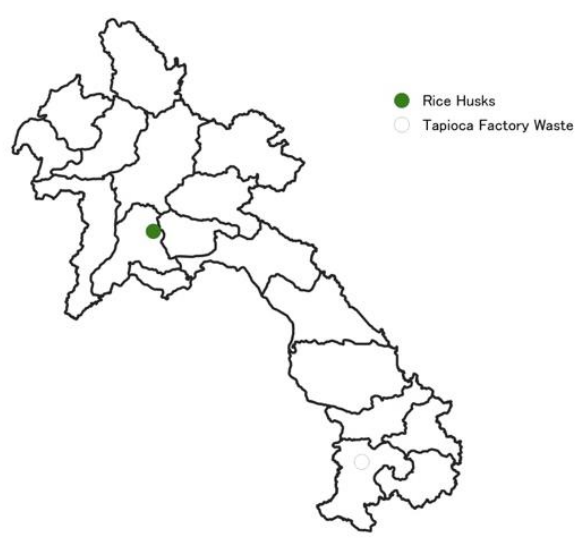

Fig. 14. The geographical location of the Japan-supported biomass projects in Laos (by feedstock).

\section{SUMMARY}

The immense potential of biomass energy in the Southeast Asian region based on its agro-industrial residues could contribute to increasing the energy supply from non-fossil fuel resources in the region as well as to reaching the target of universal electrification. Many of the technologies used in biomass projects in the Southeast Asian region uses Japanese technology [17]. In this study, we collected information about these projects and constructed a database containing 86 Japan-supported biomass projects in the region. Most of the projects were found to be in the feasibility study stage or the pilot demonstration level. In other words, most projects are still in the phase of technology development and have not reached full readiness level. While biorefining, a technology that would benefit the transportation sector, dominates the technologies used in the projects, BTG is the most popular technology among projects for the electricity generation sector. While oil palm and rice plantation residues are the most used feedstock in the projects, the geographic information system (GIS) map that we developed shows that most projects are actually located near the capital city for easy access and monitoring instead of near the location of feedstocks.

Policy-wise, government regulations in many countries of the region have created a relatively supportive environment, such as by introducing competitive FIT for biomass energy plants and fuel mandates for using biofuels. With such a promising business environment, it is expected that there will be more private companies attracted to investing in the technologies, especially those that have reached higher readiness levels. For sustainable domestic use, biomass energy conversion plants should be located near the feedstocks and end-users. Currently, several full-scale biomass-energy plants in the region, making use of the supporting regulations are run by domestic private companies. Many of these projects are located near the source of feedstock. It could be expected that as technology readiness improves, the private sector participation would increase [16], and the location of biomass-based power plants will become more distributed.

\section{CONFLICT OF INTEREST}

The authors declare no conflict of interest.

\section{AUTHOR CONTRIBUTIONS}

AHP conducted the literature review, analyzed data, and wrote the paper. PD constructed the database, analyzed data and produced the GIS maps; II developed the J-TRA methodology; HO designed and supervised the research; all authors had approved the final version.

\section{ACKNOWLEDGMENT}

The authors thank the e-Asia project members who have given valuable feedbacks during the monthly meetings in Waseda University.

\section{REFERENCES}

[1] IRENA, "Biofuel potential in Southeast Asia: Raising food yields, reducing food waste and utilising residues," 2017.

[2] IEA, "Southeast Asia energy outlook, world energy outlook special report," Paris, 2017.

[3] IRENA \& ACE, "Renewable energy outlook for ASEAN," Jakarta, 2016.

[4] WHO, "Household air pollution and health," 2018.

[5] R. Moreno-Peñaranda, A. Gasparatos, P. Stromberg, A. Suwa, A. H. Pandyaswargo, and J. A. Puppim de Oliveira, "Sustainable production and consumption of palm oil in Indonesia: What can stakeholder perceptions offer to the debate?" Sustain. Prod. Consum., vol. 4, 2015.

[6] M. Torero, "The impact of rural electrification: Challenges and ways forward," Rev. Econ. Dev., vol. 23, no. HS, p. 49, 2015.

[7] M. Kanagawa and T. Nakata, "Assessment of access to electricity and the socio-economic impacts in rural areas of developing countries," Energy Policy, vol. 36, no. 6, pp. 2016-2029, Jun. 2008.

[8] World Bank, "A bridge to universal energy access 2 country and SECTOR overview," Washington, D.C. , 2014.

[9] Republika, "Jonan Targetkan Elektrifikasi 2019 Capai 99,9 Persen," Republika Online, 2018.

[10] K. Times, "Cambodia on course to have all villages electrified by 2020 - Khmer Times," 2018.

[11] DOE, "Philippine energy plan," 2017.

[12] UNDP, "Nama for the renewable energy sector of lao PDR," 2015.

[13] K. Omura, P. A. Hadi, and O. Hiroshi, "LCCO2 of coal co-firing with imported torrefied woody biomass in Japan," E3S Web Conf., vol. 74, p. 03001, Dec. 2018.

[14] I. Renewable Energy Agency, Global Energy Transformation: A Roadmap to 2050, 2018.

[15] IEA Bioenergy, "Sustainability of bioenergy | bioenergy," 2019.

[16] I. Ihara, A. H. Pandyaswargo, and H. Onoda, "Development and the effectiveness of the J-TRA: A methodology to assess energy technology R\&D programs in Japan," EcoDePS 2018 Proceedings, 2018, pp. 109-117.

[17] Asia Biomass Office, "Biomass power generation by Japanese companies in Asia / Asia biomass energy cooperation promotion office - Asia Biomass Office," 2012.

[18] GBEP, "The global bioenergy partnership sustainability indicators for bioenergy first edition," 2011.

[19] S. Masayuki, "Guideliness to assess sustainability of biomass utilisation in East Asia," 2009.

[20] JST, "e-Asia website | alternative energy," 2017.

[21] JST, "Sustainable integration of local agriculture and biomass industries | SATREPS (science and technology research partnership for sustainable development), 2009.

[22] JST, "Development of a model system for fluidized bed catalytic gasification of biomass wastes and following liquid fuel production in Indonesia | SATREPS (science and technology research partnership for sustainable development)," 2013.

[23] JST, "Comprehensive conversion of biomass and waste to super clean fuels by new solid catalysts," 2016.

[24] R. M. Carlos and D. B. Khang, "Characterization of biomass energy projects in Southeast Asia," Biomass and Bioenergy, vol. 32, no. 6, pp. 525-532, 2008.

[25] I. Ihara, A. H. Pandyaswargo, D. Pang, and H. Onoda, "Technology readiness assessment of biomass energy projects using J-TRA method: application on southeast Asian countries," International Workshop on Environmental Engineering 2019, Japan, 2019, pp. 81-82.

[26] D. Pang, A. H. Pandyaswargo, H. Onoda, and I. Ihara, "Application of J-TRA (Japanese version of technology readiness assessment) to 
biomass utilization projects: With focus biomass energy conversion technologies in Southeast Asia," The 14th Meeting of the Institute of Life Cycle Assessment, Japan, 2019.

[27] Japan Ministry of Environment, "TRL calculating tool manual (3rd Edition)."

[28] FAO, "FAOSTAT database," 2015.

[29] ACE, "The 4th ASEAN energy outlook 2013 - 2035," ASEAN Centre for Energy, 2015.

[30] ACE and CREEI, "Asean FEED-IN-TARIFF (FIT) mechanism report," Beijing, 2018.

[31] IEA, "Feed-in tariff for very small power producers (VSPP) (excluding solar PV)," 2015.

[32] IEA, "Feed-in-tariffs for biomass and municipal waste (ministerial regulation No. 27/2014 and No. 44/2015)," 2016.

[33] Rumah Energy, "BIRU programme - Rumah energi," 2015.

[34] SEDA Malaysia, "SEDA portal," 2019.

[35] CNBC Indonesia, "Listrik di RI Mahal? Cek Dulu Tarif di Negara ASEAN Ini," 2018.

[36] IEA, "Feed-in tariff for electricity generated from biomass, ocean, run-of-river hydropower, solar and wind energy resources," 2017.

[37] APEC, "Peer review on low carbon energy policies in Viet Nam," 2016.

[38] ESDM, "FAQ: Program mandatori B20 - Kementerian ESDM Republik Indonesia," 2018.

[39] ICIS, "Thailand looks to expand commercial use of B20 biodiesel ICIS Explore," 2019.

[40] MPI, “MPI Malaysia — Biofuel (B10),” 2019.

Copyright (C) 2020 by the authors. This is an open access article distributed under the Creative Commons Attribution License which permits unrestricted use, distribution, and reproduction in any medium, provided the original work is properly cited (CC BY 4.0).

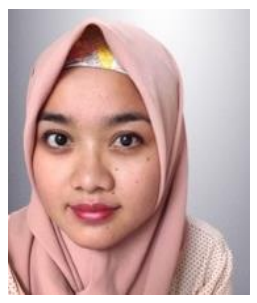

Andante Hadi Pandyaswargo is a lecturer assistant professor at the Waseda University, Graduate School of Environment and Energy Engineering, in Tokyo, Japan. Prior to her current position, she worked at the Tokyo Institute of Technology also as an assistant professor and then as a lecturer between the year 2013 to 2017 . She had research experiences with the Asian Development Bank (ADB), United Nations University (UNU), and
Institute for Global Environmental Strategies (IGES)

Dr. Pandyaswargo's published works are in the field of municipal solid waste management, life cycle assessment, biomass energy, unelectrified area energy use, and sustainable development. Her work on the sustainability discussions on oil palm plantation in Indonesia had received an award from the Institution of Chemical Engineers in 2016.

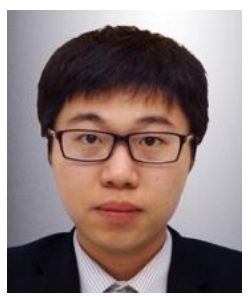

Da Pang is an enrolled master's student at the Waseda University, Graduate School of Environment and Energy Engineering in Tokyo, Japan. His current research topic is on the distribution of biomass energy projects in the Southeast Asian region, Japan, and worldwide. During his Bachelor of Engineering study in Toyo University, he was involved in the experiments of bamboo utilization in concrete material production.

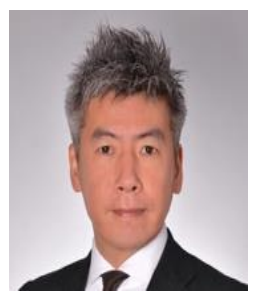

Issui Ihara is an executive officer in Delloite Tohmatsu Consulting LLC., Japan. His expertise is in project readiness analysis method development for the new and renewable energy technologies in Japan. His developed methodology has been applied in various Japanese government acquisition projects.

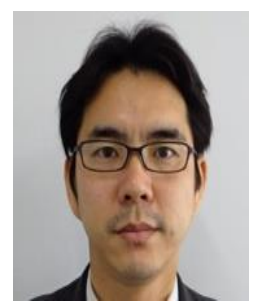

Hiroshi Onoda is a professor at the Waseda University, Graduate School of Environment and Energy Engineering, in Tokyo, Japan. He was the president of Waseda Environmental Institute Co., Ltd. between the year 2003 to 2011, and the Environmental Engineering a group leader in The Japan Society of Mechanical Engineering between the year $2010-2011$.

Prof. Onoda is advising of a number of smart city projects in Japan and currently conducting various technology development such as the Artificial Intelligence (AI) and Internet of Things (IoT) for waste management, Ultra-Light Vehicle (ULV), car battery recycling, and torrefaction of rice husk. 